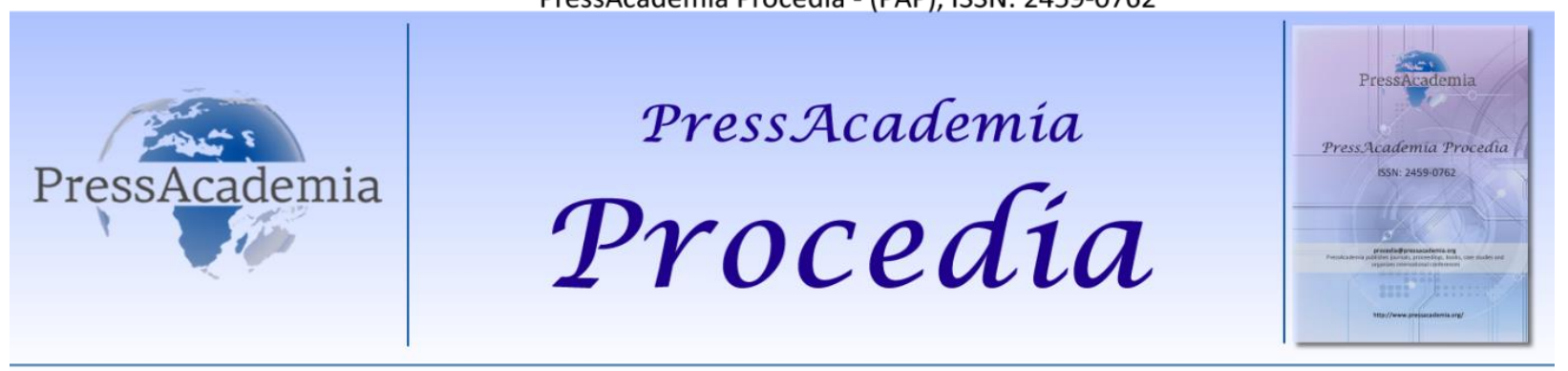

2nd World Conference on Technology, Innovation and Entrepreneurship

May 12-14, 2017, Istanbul, Turkey. Edited by Sefer Şener

\title{
AN EVALUATION OF CURRENT CAPITAL STRUCTURE DECISIONS OF TURKISH SMES
}

\author{
DOI: 10.17261/Pressacademia.2017.560 \\ PAP-WCTIE-V.4-2017(52)-p.400-408
}

Safa Demirbas ${ }^{1}$, Dilek Demirbas ${ }^{2}$

${ }^{1}$ Ministerial Advisor for Ministry of Customs and Trade, Ankara, Turkey, safademirbas@yahoo.com

${ }^{2}$ istanbul University, Faculty of Economics, İstanbul, Turkey. dilek.demirbas@istanbul.edu.tr

\begin{abstract}
Findings of this study suggest that Turkish SMEs happen to experience obstacles in raising finance to improve and develop their business environment. In particular, as information asymmetry and uncertain economic environment are the key barriers, financial constraints turn out to be main handicap for SMEs' survival. Despite its own merits, SME owners, in family business case, are reluctant to take external finance for their projects with the intention not to lose their independence and control. The main purposes of this study are firstly to investigate the issue of financing of SMEs in Turkey in the theoretical context and secondly to make policy suggestions for the future. Miller and Modigliani (1958)'s basic capital structure theory, Myers, (1984)'s trade off theory, and Myers and Majluf (1984)'s the pecking order theory are the key standing theories to examine SMEs' capital structure needs. The results of this study are similar to those reported for most Western economies that owners of SMEs follow a pecking order theory and prefer retained profit to external finance in order to cover their financing gaps.
\end{abstract}

Keywords: SMEs, capital structure theories, financing

JEL Codes: 030, N70, N75

\section{INTRODUCTION}

The capital structure mix of both small and large firms has implications for their operations and survival (Baker and Martin, 2011) as an optimal capital mix minimizes their cost of capital. All modern economies have a large number of small and medium-sized enterprises (SMEs); a similar trend is exhibited by the Turkish economy. SMEs in Turkey represent 99.85 per cent of the total businesses; 76 per cent of total employees; 63 per cent of turnover; 38 per cent of capital investment; 54 per cent of all investment; 38.9 per cent of total commercial research and development; 59.2 per cent of total export and 25.9 per cent of total credits (KOSGEB, 2014), and they play a significant role in the Turkish economy. Nevertheless, during the recent global crisis the Turkish economy shrank by 6.2 per cent annually since the fourth quarter of 2008 (Ministry of Industry and Trade, 2010), which adversely impacted on SMEs' performance and competitiveness and further exacerbated their access to external finance. The main purpose of this paper is to review the existing financial problems of SMEs in Turkey from the theoretical perspective in the capital structure literature. In particular, this paper examines whether theories that have examined the financing structures of firms in the Western economies, and elsewhere in the emerging economies, are applicable to the Turkish case with its distinct financial institutions and cultural context. The paper further investigates SMEs' financial difficulties in Turkey by evaluating the factors influencing SMEs' capital structure through theoretical and empirical studies. The key questions that this paper examines are: what are the basic theoretical approaches that explain the capital structure phenomenon in the literature which are applicable to SMEs in both developed and emerging countries? Are factors such as firm size, profit and their capital structure significant for the Turkish economy and the firm? What determines the capital structure of Turkish SMEs? What strategies or policies may be advanced for Turkish SMEs to enable them to gain competitiveness in the domestic and international markets? The paper is organized as follows. First, it considers the literature on capital structure theories and SME related studies. Second, it examines factors affecting capital structure of Turkish SMEs in theory and practice. Third, it evaluates the causes and consequence of the finance gap for SMEs in Turkey. The paper concludes by reporting conclusions drawn from the empirical literature on capital structure theory in general and for Turkey in particular. 


\section{BASIC CAPITAL STRUCTURE THEORIES AND SME RELATED STUDIES}

Efficient capital structure has implications for firms' efficiency and productivity (Jahanzeb et al., 2013). For small and large firms, having an unbalanced capital structure causes financial distress and gives rise to bankruptcy. As decision-making is a cognitive process of selecting an alternative among many possible alternatives (Jahanzeb et al., 2012; Muneer and Rehman, 2012), capital structure requires complex decision- making tactics to meet the needs of individual firms (Jahanzeb et al., 2013). The debate relating to the capital structure of firms has been of central importance for academics and policymakers around the world and has given rise to several theories (Modigliani and Miller, 1958; Kraus and Litzenberger, 1973; Kim, 1978; Myers, 1984). These theories are labelled (Frank and Goyal, 2007; Copeland and Weston, 2005) 'point of view' theories, which have provided the conceptual framework and guidelines to formulate a well-defined mathematical model to be tested for further predictions. However, such theories tend to cater for large firms and are a poor fit for SMEs.

\subsection{Basic Capital Structure Theories in General}

Modigliani and Miller (1958) proposed that firms' value is independent of capital structure. Jensen and Uhl (2008) referred to it as the first real theory on capital structure. The contention is that choice of debt or equity does not change the firm value in the situation of a perfect market (Jahanzeb et al., 2013) under certain restrictive assumptions: (a) there are no government taxes; (b) transactions are costless; (c) no insolvency costs; (d) cost of borrowing for the company is the same as lender; (e) perfect information between lender and the borrower and (f) firm earnings, pre- tax and interest, are not affected by the level of debt (Chen, 2004).

There has been an ongoing debate among academics and practitioners as to whether the trade-off theory explains the firm's capital structure in terms of whether the benefits to be derived from the tax shield are sufficient to offset the accruing cost of debt, while the firm's value of asset and investments are held constant (Myers, 1984; Kraus and Litzenberger, 1973; Hul, 2014; Berens and Cuny, 1995).

The pecking order theory (developed by Myers, 1984; Myers and Majluf, 1984) concludes that firms prefer to use retained savings (internal equity) to external loans because of information asymmetry about the firm value between the agent of the firm and the outside stakeholders (investors). Only when the internal financial resources are fully exploited do the firms seek external sources of financing. Managers prefer debt to equity finance to avoid losing control. The pecking order theory suggests that a firm prefers: first internally raised funds, such as cash reserves, then seeks external debt, and finally issues equity as a last resort. This order of finance is due to the fact that debtors are interested in security of funds and returns rather than in the value of the firm as they have the first claim on the assets of the firm (Myers, 2001).

\subsection{Basic Capital Structure Theories in the Context of SMEs}

In the capital finance literature, most research on the trade-off theory was performed on large firms due to the availability of data, but limited research has been conducted on small businesses, the dominant forms of business organization in any economy. This paper examines to what extent SMEs encounter similar problems to those of large firms regarding their capital structure in the context of the trade-off theory. Sogorb-Mira (2005) suggested that SMEs and large firms use similar considerations with regard to capital structure theories as they all encounter the same trade-off between the tax shield benefits and debt distress costs but larger firms consider these issues much more seriously. However, SMEs have limited choice in accessing external capital and experience different challenges; therefore, the experiences of small firms differ. The pecking order theory's relevance for SMEs was generally accepted wisdom among academics and policymakers in the past; however, over the last few decades, academics (Howorth, 2001; Paul et al., 2007; Atherton, 2009; Ang, 1991; Holmes and Kent, 1991) have started to question this assertion due to hurdles, choices and the cost associated with external finance. The pecking order theory's relevance stems from the fact that SME owners do not wish to use external finance that will affect their ownership rights and, therefore they often rely on and prefer internal finance for debt (Lopez-Gracia and Sogorb-Mira, 2008), especially at the start- up and development phases (Dahlstrand and Cetindamar, 2000; Giudici and Paleari, 2000; Hyytinen and Pajarinen, 2002; Chen et al., 2013). Furthermore, due to information asymmetry, access to equity markets and costs such as legal and compliance makes it expensive for small firms to raise equity finance. When dealing with equity markets, large companies often employ experts as equity is both expensive and subject to price volatility which has been shown to be particularly severe for SMEs (Chittenden et al., 1996; Ibbotson et al., 2001). Other sources of finance from private equity firms or business angels are not accessible due to the size of loan and the transaction costs which results from negotiating the complex contracts (Ou and Haynes, 2006). It is reported that financial constraints prevent SMEs from planning and acquiring long-term finance (Jensen and Uhl, 2008). Empirical evidence has suggested that there now exist a variety of pecking order theories due to varying financial and business environment facing firms (Atherton, 2009). The presence of the pecking order theory is particularly strong among SMEs operating in non- AngloSaxon countries (Sànchez-Vidal and Martìn-Ugedo, 2005) due to the underdeveloped financial environment that gives rise to the 'financing gap' (see also Holmes and Kent, 1991). 


\section{FACTORS AFFECTING THE CAPITAL STRUCTURES OF TURKISH SMES FROM THE THEORETICAL PERSPECTIVE}

Size, value added and employment among Turkish SMEs' vary from sector to sector. Turkish SMEs' share of total production is similar to other countries and trade accounts for 40 per cent, followed by manufacturing at 13 per cent and the construction sector at 5 per cent (Ministry of Industry and Trade, 2010; Turkish Statistical Institute, 2011). This supports the argument that, for Turkey, the financial environment, government policies and support mechanisms compare favourably with other developed and developing economies.

\subsection{The 'SME Financing Gap' Phenomenon and the Capital Structure of Firms}

Holmes and Kent (1991) claim that access to capital markets is limited for SMEs, regardless of whether they are located within developed or developing economies - referred to as the 'financing gap'. Many organizations, including the OECD (2006), have examined the 'financing gap' and it too reports that a large number of SMEs are unable to raise adequate finance to operate efficiently and are unable to access external finance from banks, financial markets or other finance institutions. Developed and emerging economies' experiences mirror the findings above. Hussain et al. (2006) examined and compared the financing preferences of SMEs in the UK and in China; they reported similar trends for both countries. For the SMEs' start-up finance, a large percentage of Chinese SMEs owner-managers suggested that they relied exclusively on their family and friends for unsecured finance. However, their reliance became less after two years, the respondents were able to access bank finance to an extent, and analysis after five years suggested family finance remained important. Whereas for the UK, after five years, most of the owner-managers reported that they had become bankable and acquired business loans from financial institutions. There appears to be a correlation between the growth of the economy and the bank finance used by SMEs. Japan appears to be in the lead and Turkey has merely 3.5 per cent of SMEs who have accessed bank finance (KOSGEB, 2012) that shows the financial environment is not favourable for SMEs as stated by Beck (2013). Access to finance in Eastern Europe suggests that the finance gap exists in the region. Empirical evidence reported by Cornelli et al. (1998) and Egerer (1995) suggested that leverage in Eastern Europe is found to be low and that businesses have insufficient debt finance in their capital structure; this is due to either the cost of debt or its availability. Most empirical findings point to some sort of institutional factor as the source of this problem. Turkey has many similarities with Eastern Europe because of shortcomings in the institutional environment in the Turkish system and insufficient financing opportunities due to moral hazard considerations and asymmetric information between bank managers and SME ownermanagers.

\section{EXAMINING CAPITAL STRUCTURES OF TURKISH SMES FROM THE EMPIRICAL PERSPECTIVES}

The Turkish SME literature suggests that a firm's capital structure is composed of variables, such as the firm size, asset tangibility, profitability and growth. These variables are used to test the trade-off and pecking order theories to make predictions of the impact of the variables on the firm's capital structure. An increase in the size of Turkish SMEs will decrease the probability of bankruptcy and will reduce information asymmetry problems (Çakova, 2011). In the next section, capital structure theory related to empirical studies is evaluated to understand the financial difficulties encountered by SMEs in Turkey and to discuss policy implications. To examine the capital structure of the Turkish SMEs, Korkmaz et al. (2007) carried out an empirical study among 37 firms over the seven year period from 1977 to 2004 . To study what determinates the firm's capital structure, they employed proxy variables such as the firm size, risk (measured by the variability in net sales), profitability, tax shield and the firm growth rate (change in Gross Domestic Product). The results of the study found that the most important factors that influence SMEs capital structure were the firm's profitability, firm risk and non-debt tax shields. Korkmaz et al. (2007) also observed in this study that there is a relation- ship between the firm's assets and its leverage; an increase in a firm's assets leads to an increase in the firm's leverage. Korkmaz et al. (2009) tested the same model for 16 companies from the auto parts industry and confirmed the results of their 2007 research. Çakova (2011) analyses the factors of capital structure of SMEs from the manufacturing sector in Turkey. Çakova (2011) used data from 1998 to 2008 and had 4,003 firms with average annual observations of 44,029. This research used a twoway fixed effect model estimation to study the short and long term debt ratios of SMEs, and supported the assertion that the capital structure of SMEs can be explained using the pecking order theory. The results of this study also confirm that there is an inverse relationship between SMEs average debt ratios and economic conditions in Turkey. The study also found, taking into account the industry variations, that firm's characteristics are important in explaining capital structure adapted by the Turkish SMEs. A major study carried out by Köksal and Orman (2014) for the period 1996-2009, using the data from Central Bank of the Republic of Turkey (CBRT), report the comparative tests of the trade-off and pecking order theories, for small, large and publicly traded firms for the Turkey. Köksal and Orman's (2014) findings report that the tradeoff theory is in a better position to explain the capital structure of firms than the pecking order theory. The results of Köksal and Orman's (2014) study support the earlier studies findings and they reported that the trade-off theory is more suited to explain the capital structure of larger firms operating in economies that have a stable economic environment. 
A study carried out by Booth et al. (2001) for ten developing countries (including Turkey) tested whether country-specific variables explain the capital structure of SMEs. They reported that general debt level of SMEs increases as the ratio of fixed asset to total asset rises, and it is the case for non-debt tax shields, growth rates and firm size. These findings are consistent with earlier studies discussed above. These findings suggest that financial institutions use asset profile and the age profile of the business to evaluate risk of the business. Their second finding is plausible - that financial advantage is negatively correlated with earnings, volatility and the probability of bankruptcy - as these variables make a limited contribution towards collateral and can encounter greater variability. As observed in the empirical studies that tested capital structure theories, profitability, firm risk, and non-debt tax shields are the most important factors that influence SMEs capital structure in Turkey (Demirbas et. al. 2011; Demirbas, 2011; Demirbaş, 2007). Turkish SMEs, particularly small manufacturing firms, follow the pecking order hypothesis in their debt behaviour, when the economic environment is not stable. In response, the Turkish government organization, KOSGEB has formulated policies for SMEs to enhance their competitiveness by enabling them to enhance their research and development and innovation capacities. Steps have also been taken to improve cooperation among SMEs themselves, support new entrepreneurial activities and enhance access to finance (KOSGEB, 2009). These outcomes would be achieved through improving the flow of information, financial education among SME owner-managers, and information problems through training of owners of SMEs. With these programs, KOSGEB has helped to increase the share of SME loans. Despite the fact that KOSGEB actively engages with SMES and develops plans to increase the competitiveness of Turkish SMEs to minimize their financial problems, Turkish SMEs continue to experience many obstacles in accessing finance. In Turkey, private equity and venture capital funds are relatively insignificant in comparison with the bank finance for SMEs. The emergence and rise of private equity can be traced back to 1993 when the regulation approved the formation of venture capital firms - revised in 2003. The equity based transaction was conducted in 1995 by a foreign investment firm. Since 1996, a number of Turkish private equity firms have been set up but their size and participation within the sector is limited. The insignificance of venture capital firms can be gleaned from their numbers. In 2014, there were only five venture capital investments trusts listed on the Istanbul Stock Exchange and had a market value of US\$480m. However, due to the nature of loan size approved and legal issues, venture capital has limited relevance for a large number of SMEs.

There have been some bold government initiatives to mitigate the financial problems of SMEs in Turkey. To support SMEs, the Emerging Companies Market was established within the ISE after the financial crisis in 2009. To enable SMEs to tap into this fund, SMEs were exempted from the quantitative requirements of exchange trading. Furthermore, to engage and support SMEs, Capital Markets Board of Turkey (CMB) and the Central Securities Depository of Turkey (ISE and CRA) reduced their fees. Furthermore, to support SMEs, the bond market was promoted through the revision of financial regulations to revive the market, which had a very positive outcome in that the corporate debt securities market expanded significantly since 2010 and it received support from the banks. There is now more willingness among the financial institutions to issue debt finance. In 2012, 98 financial institutions issued debt securities and instruments and their value exceeded US\$2bn. Furthermore, 11 non- financial corporations also issued bonds worth US\$490m (KOSGEB, 2012). Despite the mentioned initiatives and innovations, the financial problems of SMEs are still a major issue for the whole sector due to structural and institutional reluctance and rigidities.

\subsection{Main Reasons to Seek Access to Finance for Turkish SMEs}

It has been recognized that (Turkish Industrial Strategy Document, Munich Personal RePEc Archive (MPRA, 2013)) SMEs in Turkey have difficulties in acquiring access to finance due to four main reasons:

1. the credit limit given to the banking sector due to financial reorganiza- tion of 2001;

2. underdevelopment of the capital market;

3. the underdeveloped financial structure to support SMEs; and

4. administrative and legal obstacles to access finance.

These findings are supported by Kaya and Alpkan (2012) and Demirbas et al., (2011), who reported that a lack of financial information, poor experience of business decision-making among owner-managers, the underdevelopment of finan- cial systems and the environment, a lack of credit volume and the cost of credit are the main financial obstacles faced by SMEs in Turkey. However, Şeker and Correa (2010) indicate that SMEs in Turkey are more dependent on bank finance than other countries to fund their fixed assets. The bank funding for fixed assets in Turkey accounts for 47 per cent of all loans, backedup with collateral, yet SMEs are finding difficult to secure loans for operating cash flow and this is of particular concern during the periods of financial crises. Since the Turkish SMEs primarily depend on bank loans and the recent crisis revealed that bank financing is not a reliable source of financing, especially during periods of financial crises. In particular, after the financial crisis of 2008 , that persuaded the banks to strengthen their capital requirement, which has created additional 
challenges for SMEs to secure bank loans. Therefore, there is the need for policymakers to produce conducive policies and environments to provide well-diversified funding sources for SMEs to promote growth and expansion of SMEs in Turkey. In response, the government and regulators have to promote policies for banks to improve access to loans and promote the equity markets to provide finance for SMEs. Yet there is no evidence that SMEs are able to access equity markets; even in well-developed economies equity markets such as private equity and venture capital investments fail to meet the needs of SMEs. ICSA (2013) reported that there are also a few securitized products backed specifically by SME loans. There is a move towards creating structure and developing capabilities of SMEs to secure formal external finance through education and training. In the Turkish equity market, government has promoted the specific segments for SMEs through relaxing the listing and disclosure requirements in comparison with the main markets. The other strategy adopted by the government is to provide incentives for SMEs to encourage them to list. One such initiative is to promote Over-The-Counter (OTC) markets to support the unlisted SMEs. The Turkish government has encouraged the market advisors to provide advice to SMEs to gain listing on the exchanges (Nurrachmi and Foughali, 2012).

Müftüoğlu (2009) suggested training, mentoring, creating awareness initiatives for SMEs and training for bank lending managers to narrow the information gap, especially at the early stage where the business owners do not have enough finance knowledge, experience or necessary information about how the bank operates. The most important problem facing SMEs in Turkey is related to the high credit cost that adversely affects their survival. In addition, they do not have enough financial or physical asset security to negotiate competitive deals with the banks. Issuing of credit warranty is another hurdle or barrier for SMEs in Turkey. Because of the size of SMEs and their vulnerability in terms of management, the lending organizations see them as risky propositions. Hence providers of finance seek excessive collateral that works against the interests of SMEs. Another big issue for financial institutions is the pilferage of the loans specially approved for business activities; use of the loan other than business purposes increase the risk for the lenders (Kaya and Alpkan, 2012; Demirbas et al. 2011). Therefore, research conducted with SMEs supports the view that the initial capital is provided by the individual from their own savings and, second, that the debt finance from their family and friends and the bank loan is used as a last resort. It is suggested (Kaya and Alpkan, 2012) that in Turkey some SMEs are reluctant to use interest-bearing loans, due to their religious beliefs. Unlike Western economies, the Turkish government does not offer loan guarantee schemes to banks to support small businesses which lack collateral to secure finance. This leads enterprises to secure loans at higher interest rates in the absence of collateral or forgo the opportunity to enter self-employment. Finance constraints compound problems for SMEs. Lack of liquidity affect SMEs' purchases of stock on credit as they lack credit history, without which the provider of goods is not able to evaluate risk (Kaya and Alpkan, 2012). However, over time as the business develops a track record and a relationship - the access to purchase goods on credit improves a pattern similar to that observed in the UK. Entrepreneurs in Turkey are averse to external finance as they fear loss of control and hence rely on their savings and debt from close friends that often leaves small enterprises to be undercapitalized (Kaya and Alpkan, 2012; Ekinci, 2003).

\section{CONCLUSION}

The application, usability and role of the pecking order theory for SMEs have evolved over recent decades. Paul et al. (2007) suggest that the rationale for the applicability of the pecking order theory to SMEs is due, first, to the tendency of SME owner-managers to demonstrate a strong aversion to losing control over their business when new financiers are involved (Berggren et al., 2000; Paul et al., 2007, Cosh and Hughes, 1994; Frank and Goyal, 2003, 2007). Consequently, the ownermanagers of SMEs prefer retained savings as a source of finance to minimize the risk of losing control of their business (Newman et al., 2011). Secondly, due to poor management and financial control, SMEs tend to exhibit higher levels of asymmetric information when compared with the larger firms. This is due to the inability of SMEs to provide adequate financial and historical performance data to banks to use to make the lending decisions (Binks and Ennew, 1996; Reid, 1996; Hall et al., 2004), and small firms have to provide either collateral to secure external debt, use internal finance or borrow short-term or are more likely to rely upon internally generated retained profit that reduces their dependence on external finance. Therefore, the expectation, in line with the pecking order theory, is the more profitable the firm is, the less likely is the need for that firm to borrow externally, but is more likely to secure external debt.

There is consistency in the findings of empirical research that investigated the capital structure of the Turkish SMEs and, indeed, successive studies have concluded that the pecking order theories are a better fit to explain the capital structure of Turkish SMEs (Çakova, 2011; Korkmaz et al., 2007, 2009; Yıldız et al., 2009; Acaravcı and Doğukanlı, 2004; Köksal and Orman, 2014). This suggests that the less profitable the SMEs are in Turkey, the more likely they are to seek external finance. Our paper concludes that Turkish companies mainly follow the pecking order hypothesis in their capital structure for two principal reasons. First, because Turkish SMEs experience a 'finance gap', which prevents them from acquiring external finance at low cost. Second, they lack financial education and awareness about all the possibilities and aspects of external finance; thus the main long-term source of finance is retained earnings followed by bank loans. Turkish SMEs form the backbone of Turkish economic cohesion and social order, therefore it is imperative for the government and policy 
makers to create and formulate progressive policies to support and encourage creation, and growth of SMEs by improving access to finance. Second, information asymmetry between insiders (owner-managers) and outsiders (lenders) gives rise to moral hazard that may be managed through financial education and the training of owner-managers of Turkish SMEs. It is generally accepted that to facilitate external finance for SMEs, there is a need for a robust legal, institutional and regulatory environment. In such conditions the government or banks initiatives alone cannot ease the financial problems of SMEs. Therefore, Turkish national and local governments need to initiate long-term governmental policies and institutional reforms to enhance the legal, institutional and regulatory environment to enable SMEs to access external finance.

\section{REFERENCES}

Acaravcı, S. and Doğukanlı, H. (2004), 'Testing on manufacturing sector of determinants of capital structure in Turkey', iktisatişletmeveFinans, 19 (225): 43-57.

Adedeji, A. (2002), 'A cross-sectional test of pecking order hypothesis against static trade off theory on UK Data', Working Paper, Birmingham: University of Birmingham.

Akkaya, G.C. and Güler, S. (2008), 'Capital structure, assets and profitability: an application on manufacturing firms', iktisatişletmeveFinans, 23 (263): 41-52.

Altı, A. (2006), 'How persistent is the impact of market: timing on capital structure?', The Journal of Finance, 61 (4): 1681-1710.

Altı, A. and Sulaeman, J. (2012), 'When do high stock returns trigger equity issues?', Journal of Financial Economics, 103 (1): 61-87.

Ang, J.S. (1991), 'Small business uniqueness and the theory of financial management', Journal of Small Business Finance, 1 (1): 1-13.

Atherton A. (2009), 'Rational actors, knowledgeable agents: extending pecking order considerations of new venture financing to incorporate founder experience, knowledge and networks', International Small Business Journal, 27 (4): $470-495$.

Baker, H.K. and Martin, G.S. (2011), Capital Structure and Corporate Financing Decisions: Theory, Evidence, and Practice, London: John Wiley and Sons.

Baker, M. and Wurgler, J. (2002), 'Market timing and capital structure', The Journal of Finance, 57 (1): 1-32.

Bayraktaroğlu, A., Ege, ì. and Yazıcı, N. (2013), 'A panel data analysis of capital structure determinants: empirical results from Turkish Capital Market', International Journal of Economics and Finance, 5 (4): 131-140.

Beck, T. (2013), 'Lessons from the literature - bank financing for SMEs', National Institute of Economic Review, 225 (1): $23-38$.

Berens, J.L. and Cuny, C.J. (1995), 'The capital structure puzzle revisited', Review of Financial Studies, 8 (5): $1185-1208$.

Berggren, B., Olofsson, C. and Silver, L. (2000), 'Control aversion and the search for external financing in Swedish SMEs', Small Business Economics, 15 (3): 233-242.

Binks, M.R. and Ennew, C.T. (1996), 'Growing firms and the credit constraint', Small Business Economics, 8 (1): 17-25.

Bistrova, J., Lace, N., and Peleckiene, V. (2011), 'The influence of capital structure on Baltic corporate performance', Journal of Business Economics and Management, 12 (4): 655-669.

Booth, L., Aivazian, V., Demirguc-Kunt, A., and Maksimovic, V. (2001), 'Capital structures in developing countries', The Journal of Finance, 56 (1): 87-130.

Çakova, U. (2011), 'Capital structure determinants of Turkish SMEs in manufacturing industry', unpublished Master's Thesis, Ankara, Turkey: Bilkent University.

Chen, D.H., Chen, C.D., Chen, J. and Huang, Y.F. (2013), 'Panel data analyses of the pecking order theory and the market timing theory of capital structure in Taiwan', International Review of Economics and Finance, 27 (C): 1-13.

Chen, J. (2004), 'Determinants of capital structure of Chinese-listed companies', Journal of Business Research, 57 (12): $1341-1351$.

Chittenden, F., Hall, G., and Hutchinson, P. (1996), 'Small firm growth, access to capital markets and financial structure: review of issues and an empirical investigation', Small Business Economics, 8 (1): 59-67.

Copeland, T.E. and Weston, J.F. (2005), Financial Theory and Corporate Policy (4th edition), Reading MA: Addison-Wesley.

Cornelli, F., Portes, R., and Schaffer, M. (1998), 'The capital structure of firms in Central and Eastern Europe', in O. Bouin, F. Coricelli and F. Lemoine (eds), Different Paths to a Market Economy: China and European Economies in Transition, s.I.: CEPR/CEPII/OECD.

Cosh, A.D. and Hughes, A. (1994), 'Size, financial structure and profitability', in A. Hughes and D.J. Storey (eds), Finance and the Small Firm, London: Routledge, pp. 1-50.

Cressy, R. and Olofsson, C. (1997a), 'European SME financing: an overview', Small Business Economics, 9 (2): 87-96. 
Cressy, R. and Olofsson, C. (1997b), 'The financial conditions for Swedish SMEs: survey and research agenda', Small Business Economics, 9 (2): 179-194.

Dahlstrand, A.L. and Cetindamar, D. (2000), 'The dynamics of innovation financing in Sweden', Venture Capital, 2 (3): $203-221$.

Demirbaş D. (2011). Formal Informal Environmental and Skill Barriers for Entrepreneurs Microeconometric Evidence from 197 Turkish SMEs. Journal of Business and Policy Research, 6(2), 15-37. (Yayın No: 1774689)

Demirbaş D, Hussain, J. and Matlay, H. (2011). Owner Managers Perceptions of Barriers to Innovation Empirical Evidence from Turkish SMEs. Journal of Small Business and Entrepreneur Development, 18(4), 764-780. (Yayın No: 1774441)

Demirbaş D. (2010). How do entrepreneurs percieve barriers to innovation An Emprical evidence from Turkish SMEs. Northumbria Üniversity, Working Paper Series, 3(7), 12-27. (Yayın No: 2157151)

Egerer, R. (1995), Capital Markets, Financial Intermediaries, and Corporate Governance: An Empirical Assessment of the Top Ten Voucher Funds in the Czech Republic, New York: World Bank.

Ekinci, M.B. (2003), 'Türkiye' de KOBi' lerin Kurumsal Gelişimi ve Finansal Sorunları', İstanbul: AskonYayınları.

Fischer, E.O., Heinkel, R. and Zechner, J. (1989), 'Dynamic capital structure choice: theory and tests', Journal of Finance, 44 (1): $19-40$.

Flannery, M.J. and Rangan, K.P. (2006), 'Partial adjustment toward target capital struc- tures', Journal of Financial Economics, 79 (3): $469-$ 506.

Frank, M.Z. and Goyal, V.K. (2003), 'Testing the pecking order theory of capital structure', Journal of Financial Economics, 67 (2): $217-248$.

Frank, M.Z. and Goyal, V.K. (2007), 'Trade-off and pecking order theories of debt' in B. EspenEckbo (ed.), Handbook of Corporate Finance: Empirical Corporate Finance, Boulder, CO: Elsevier, pp. 135-202.

Giudici, G. and Paleari, S. (2000), 'The provision of finance to innovation: a survey con- ducted among Italian technology-based small firms', Journal of Small Business Economics, 14 (1): 37-53.

Hall, G., Hutchinson, P. and Michaelas, N. (2004), 'Determinants of the capital structures of European SMEs', Journal of Business Finance and Accounting, 31 (5-6): 711-728.

Hamilton, R.T. and Fox, M.A. (1998), 'The financing preferences of small firm owners', International Journal of Entrepreneurial Behaviour and Research, 4 (3): 239-248.

Holmes, S. and Kent, P. (1991), 'An empirical analysis of the financial structure of small and large Australian manufacturing enterprises', The Journal of Small Business Finance, 1 (2): 141-154.

Howorth, C. (2001), 'Small firms' demand for finance: a research note', International Small Business Journal, 19 (4): 78-86.

Hull, R. van 't. (2014), Determinants of the capital structure of Dutch SMEs, PhD Thesis, Twente University of Twente, Netherlands.

Hussain, J., Millman, C. and Matlay, H. (2006), 'SME financing in the UK and in China: a comparative perspective', Journal of Small Business and Enterprise Development, 13 (4): 584-599.

Hyytinen, A. and Pajarinen, M. (2002), 'Financing of technology intensive small business: some evidence from the ICT industry', Discussion Paper, 813, Helsinki: The Research Institute of the Finnish Economy.

Ibbotson, R.G., Sindelar, J.L. and Ritter, J. (2001), 'Initial public offerings', Journal of Applied Corporate Finance, 6 (2): 37-45.

ICSA (2013), Financing of SMEs through Capital Markets in Emerging Market Countries, London: ICSA Emerging Markets Committee.

Jahanzeb, A., Muneer, S. and Rehman, S.U. (2012), 'Implication of behavioral finance in investment decision-making process', Information Management and Business Review, 4 (10): 532-536.

Jahanzeb, A., Rehman, S.U., Bajuri, N.H., Karamiand, M. and Ahmadimousaabad, A. (2013), 'Trade-off theory, pecking order theory and market timing theory: a comprehensive review of capital structure theories', International Journal of Management and Commerce Innovations, 1 (1): 11-18

Jensen, N.S and Uhl, F.T. (2008), Capital Structure in European SMEs. An Analysis of Final and Country Specific Variables in Determining Leverage, Aarhus: Aarhus School of Business.

Jordan, J., Lowe, J. and Taylor, P. (1998), 'Strategy and financial policy in UK small firms', Journal of Business Finance and Accounting, 25 (12): $1-27$.

Karadeniz, E., Kandır, S.Y., Balcılar, M. and Onal, Y.B. (2009), 'Determinants of capital structure: evidence from Turkish lodging companies', International Journal of Contemporary Hospitality Management, 21 (5): 594-609.

Karadeniz, E., Kandır, S.Y., İskenderoğlu, Ö. and Önal, Y.B. (2011), 'Firm size and capital structure decisions: evidence from Turkish lodging companies', International Journal of Economics and Financial Issues, 1 (1): 1-11. 
Kaya, S. and Alpkan, L. (2012), 'Problems and solution proposals for SMEs in Turkey', Emerging Markets Journal, 2 (2): $30-45$.

Kaygın, B., Tankut, A.N. and Çaylı, M. (2008), 'The structural analysis of small and medium size furniture enterprises in Turkey based on production, capacity use and working environment', African Journal of Biotechnology, 7 (24): 4628-4634.

Kim, E.H. (1978), 'A mean-variance theory of optimal capital structure and corporate debt capacity', Journal of Finance, 33 (1): $45-63$.

Köksal, B. and Orman, C. (2014), 'Determinants of capital structure: evidence from a major developing economy', Working Paper, 14/26, Ankara: Central Bank of the Republic of Turkey.

Korkmaz, T., Albayrak, A.S. and Karataş, A. (2007), 'The analysis of the capital structure of the SMEs registered in the ISE: 1997-2004', iktisatişletmeveFinans, 22 (253), 79-96.

Korkmaz, T., Başaran, Ü. and Gökbulut, R.D. (2009), 'The determinant factors of the capital structure of the automotive and auto parts companies registered in the ISE: panel data analysis', iktisatişletmeveFinans, 24 (277): 29-60.

KOSGEB (2012), Enhancing the Competitiveness of SMEs in Turkey. Submitted to the 28th Session of the COMCEC, Ankara: KOSGEB.

KOSGEB (2014), Financing of SMEs by KOSGEB. SME Development Centers, Ankara: KOSGEB.

Kraus, A. and Litzenberger, R.H. (1973), 'A state-preference model of optimal financial leverage', Journal of Finance, 28 (4): $911-922$.

Leary, M.T. and Roberts, M.R. (2005), 'Do irms rebalance their capital structures?', Journal of Finance, 60 (6): $2575-2616$.

Lopez-Gracia, J. and Sogorb-Mira, F. (2008), 'Testing trade-off and pecking order theories financing SMEs', Small Business Economics, 31 (8): 117-136.

Michaelas, N., Chittenden, F. and P. Poutziouris (1999), 'Financial policy and capital structure choice in UK SMEs: Empirical evidence from company panel data', Small Business Economics, 12 (2): 113-130.

Ministry of Industry and Trade (2010), Turkish Industrial Strategy Document 2011-2014, Ankara: Ministry of Industry and Trade.

Modigliani, F. and Miller, M.H. (1958), 'The cost of capital, corporation finance and the theory of investment', American Economic Review, 48 (3): 261-297.

Müftüoğlu, T. (2009), 'SME support policies in Turkey after 1990: review, evaluation and suggestions', Paris: Agence Française de Développement, mimeo.

Muneer, S. and Rehman, S.U. (2012), 'Materialization of behavioral finance and behavio- ral portfolio theory: a brief review', Journal of Economics and Behavioral Studies, 4 (8): 431-435.

Munich Personal RePEc Archive (MPRA) (2013), The Development of SMEs in Turkey, Munich: Munich Personal RePEc Archive.

Myers, S.C. (1984), 'The capital structure puzzle', Journal of Finance, 39 (3): 575-592. Myers, S.C. (2001), 'Capital structure', Journal of Economic Perspective, 15 (2): 81-102.

Myers, S.C. and Majluf, N. (1984), 'Corporate financing and investment decisions when firms have information that investors do not have', Journal of Financial Economics, 13 (4): 187-221.

Newman, A., Gunessee, S., and Hilton, B. (2011), 'Applicability of financial theories of capital structure to the Chinese cultural context: a study of privately owned SMEs', International Small Business Journal, 30 (1): 65-83.

Nurrachmi, R. and Foughali, K.A. (2012), 'The development of SMEs in Turkey', MPRA Paper, No. 46817, Munich: Munich Personal RePEc Archive.

OECD (2006), The SME Financing Gap - Theory and Evidence, Volume 1, Paris: OECD Publishing.

Ou, C. and Haynes, G.W. (2006), 'Acquisition of additional equity capital by small firms: findings from the National Survey of Small Business Finances', Small Business Economics, 27 (2-3): 157-168.

Özer, B. and Yamak, S. (2000), 'Self-sustaining pattern of finance in small business: evidence from Turkey', International Journal of Hospitality Management, 19 (3): 261-273.

Paul, S., Whittam, G. and J. Wyper, J. (2007), 'The pecking order hypothesis: does it apply to start-up firms?', Journal of Small Business and Enterprise Development, 14 (1): 8-21.

Reid, G.C. (1996), 'Financial structure and the growing small firm: theoretical underpinning and current evidence', Small Business Economics, 8 (1): 1-7.

Sànchez-Vidal, J. and Martìn-Ugedo, J.F. (2005), 'Financing preference of Spanish firms: the pecking order theory in the context of small and medium-sized enterprises: a note evidence on the pecking order theory', Review of Quantitative Finance and Accounting, 25 (1): $341-355$.

Şeker, M. and Correa, P.G. (2010), 'Obstacles to growth for small and medium enterprises in Turkey', WPS 5323, New York NY: World Bank. 
Sogorb-Mira, F. (2005), 'How SME uniqueness affects capital structure: evidence from a 1994-1998 Spanish data panel', Small Business Economics, 25 (5): 447-457.

Turkish Statistical Institute (2011), SME Statistics, Ankara: Turkish Statistical Institute. Yıldı, M.E., Yalama, A., and Sevil, G. (2009), 'Testing capital structure theory using panel data regression analysis: an empirical evidence from Istanbul Stock Exchange manufacturing firms', iktisatişletmeveFinans, 24 (278): 25-45. 